\title{
AN EARLY AMERICAN SCHOOLBOOK
}

\author{
BY ORAL S. COAD
}

Dr. Coad is Professor Emeritus of English at Douglass College

$7 \mathrm{HE}$ author of a recent study in educational history states that Noah Webster in 1785 brought out the first school

1 reader to be compiled in America. ${ }^{1}$ Another recent investigator points out that one of the earliest American books "which might be called literature texts" was Miscellanies, Moral and Instructive. ${ }^{2}$ This little volume, with the full title of Miscellanies, Moral and Instructive, in Prose and Verse; Collected from Various Authors, for the Schools, and Improvement of Young Persons of Both Sexes, was first published at Philadelphia in 1787 . It therefore becomes one of the earliest American readers as well as one of the earliest American textbooks of literature, and the ownership by the Rutgers University Library of three copies, one of them purchased a short while ago, is a matter of some interest.

That Miscellanies, Moral and Instructive met a felt need would seem to be indicated by the number of editions it enjoyed and the number of places in which it was reissued during the next fifteen years. After the first Philadelphia edition of 1787 it reappeared as follows: London, I 787 ; Dublin, I 789 ; London, I 790 ; Burlington, N.J., I792; London, I 793; Philadelphia, I 793 ; (?) New Bedford, Mass., I 794; (?) Boston, I 795; Burlington, I 796; Philadelphia, I $802 .^{3}$ The Rutgers copies are from the two Burlington issues and the Philadelphia issue of I 793. These three editions range from I 80 to $2 \mathrm{O} 2$ pages but differ only very slightly in contents.

The various editions were all published anonymously but in some of its later listings the Library of Congress gives the compiler's name as "[Moore, Milcah Martha (Hill)] I 740-I 829." This clearly correct attribution is based on statements to be found in Letters of

1 John A. Nietz, Old Textbooks (Pittsburgh, I961), p. 64.

2 Charles Carpenter, History of A merican Schoolbooks (Philadelphia, 1 963), p. I6o.

${ }^{3}$ This list is derived from Charles Evans's American Bibliography and the printed catalogues of the Library of Congress and the British Museum. Information about the New Bedford and Boston editions consists of advertisements, which may merely indicate that copies of other editions were for sale. 
Doctor Richard Hill and His Children. ${ }^{4}$ Mrs. Moore, daughter of Dr. Richard Hill and wife of Dr. Charles Moore, was a Quaker who resided chiefly in Burlington and Montgomery Square, Pa. (near Philadelphia), and who was buried in the Burlington Friends' Burial Ground. She has been characterized as "a woman of fine intelligence and cultivation." Her interest in education and her benevolence are attested by her endowment of a girls' school at Montgomery with the profits from the book under discussion. ${ }^{6}$

In her preface the editor remarked on the lack of proper books for the use of the schools and rightly looked upon her compilation as a pioneer effort toward the end indicated in Pope's famous couplet, which appears as a motto on the title page:

'Tis Education forms the common Mind;

Just as the Twig is bent, the Tree's inclin'd.

With pride no doubt she also quoted a commendation by Benjamin Franklin, who, having perused a part of the manuscript, endorsed it as highly useful for the rising generation.

The compiler probably hoped to improve the reading ability and literary taste of the young persons into whose hands the book would fall. Consequently she chose her passages, all short and mostly unidentified in the text, from writers such as Plutarch, Marcus Aurelius, Bacon, Pope, Prior, Addison, Johnson, Young, Cowper, Hannah More, and Mrs. Chapone, once noted for her Letters on the Improvement of the Mind.

But a higher purpose of the school reader, in Mrs. Moore's belief, was obviously the training of character. Accordingly these excerpts are uniformly didactic and calculated to sow the seeds of piety, industry (the ant is frequently cited as an exemplar), contentment with one's lot, honesty, prudence, and the like. God, the grave, and heaven are offered constantly for the contemplation of the youthful mind. Nowhere is there a hint of humor or story-telling (barring a poem on "Pharaoh's Daughter") or patriotism (perhaps because of the Quaker affiliation).

4 John Jay Smith, ed. (Philadelphia, I 854), pp. 202-203, 288-289.

5 Pennsylvania Magazine of History and Biography, VIII (1884), I5; X (1886), I04; XXIV (1900), 152.

${ }^{6} \mathrm{John}$ Jay Smith, op. cit., p. 202. 
Webster, in the preface to his reader, announced that his pathfinding effort would be attentive not only to the morals of the young but to their political interests as well. Appropriately his selections include a history and geography of each state in the Union, some Revolutionary orations, and other patriotic items. And the motto on his title page is this sentence from the French statesman Mirabeau: "Begin with the Infant in his Cradle: Let the first Word he lisps be Washington."”

On the whole Mrs. Moore's textbook is considerably more somber and oppressive than that of her immediate predecessor in the field. Both the adult style and the solemn didacticism of her passages drawn together for the benefit of immature minds are typified in these samples: "Let us be particularly careful to shun all occasion of superfluous discourse, and watch over our words, that we utter nothing but what may tend to the glory of God, or the good of our neighbor." "The seeds of those spiritual joys and raptures, which are to rise up and flourish in the soul to all eternity, must be planted in her, during her present state of probation." "The surest way to purchase happiness, must be, to let as little of our time as possible slip away unobserved and unimproved." "The highest learning, is to be wise; and the greatest wisdom, is to be good."

However unpalatable such precepts might be to the school child of today and however outmoded a modern educator might consider such technique, Mrs. Moore apparently felt that her own upbringing had profited therefrom. In a letter quoted by one of her sisters in I 797 she recalled that "our dear mother and sister used to make me write [that is, copy] some little piece of prose or poetry every day, and as I knew it would please them, I continued it for many years after I grew up. I suppose many hundred of the 'Miscellanies' were selected by them for me to copy, when I was a child ..."”

Miscellanies, Moral and Instructive, then, is of some interest as a bibliographical item and of some value as an illustration of twigbending measures employed in the last years of the eighteenth century.

${ }^{7}$ Noah Webster, An American Selection of Lessons in Reading and Speaking, 3 rd ed. (Philadelphia, 1787 ). The Rutgers Library has a copy of this edition.

8 John Jay Smith, op. cit., p. 289. 